\title{
SELF-REPORTED PHYSICAL ACTIVITY IN PERCEIVED NEIGHBORHOOD IN CZECH ADULTS - NATIONAL STUDY
}

\author{
Josef Mitáśs ${ }^{1, *}$, Karel Frömel ${ }^{1}$, Svatopluk Horák ${ }^{1}$, Jiří Nykodým ${ }^{2}$, Oldřich Racek ${ }^{2}$, \\ Emil Řepka ${ }^{3}$, Zdeněk Šebrle ${ }^{3}$, Ladislav Bláha ${ }^{4}$, Aleš Suchomel ${ }^{5}$, Dana Feltlová ${ }^{6}$, Igor Fojtík ${ }^{7}$, \\ Petr Valach ${ }^{8}$, Tomáš Klobouk ${ }^{8}$
}

\author{
${ }^{1}$ Faculty of Physical Culture, Palacký University, Olomouc, Czech Republic \\ ${ }^{2}$ Faculty of Sports Studies, Masaryk University, Brno, Czech Republic \\ ${ }^{3}$ Faculty of Education, University of South Bohemia, České Budějovice, Czech Republic \\ ${ }^{4}$ Faculty of Education, Jan Evangelista Purkyně University, Ustí nad Labem, Czech Republic \\ ${ }^{5}$ Faculty of Education, Technical University of Liberec, Liberec, Czech Republic \\ ${ }^{6}$ Faculty of Education, University of Hradec Králové, Hradec Králové, Czech Republic \\ ${ }^{7}$ Pedagogical Faculty, University of Ostrava, Ostrava, Czech Republic \\ ${ }^{8}$ Faculty of Education, University of West Bohemia, Plzeň, Czech Republic
}

Submitted in April, 2013

\begin{abstract}
BACKGROUND: International studies associate physical activity (PA) to other factors such as the environment, culture, and policy. External influences on lifestyle and PA, such as the effect of the physical and built environment, are discussed. Neighborhood environments seem to be one of the important aspects in prevention of unhealthy lifestyle and physical inactivity research.

OBJECTIVE: The main objective is to analyze the relationship between PA and neighborhood environment of the adult population of the Czech Republic. The study tries to define the basic correlates of PA in relation to environmental and other socio-demographic factors.

METHODS: Nationwide data collection of adult PA was done regionally in the Czech Republic between the years 2005-2009 using the IPAQ (long) and ANEWS questionnaires.

RESULTS: The results show that males realize significantly more vigorous PA than females while females realize more moderate PA and walking than males. PA of residents of smaller communities is higher than those living in large cities. The level of weekly PA does not significantly affect the neighborhood walkability $[\mathrm{H}(3,8708)=19.60$; $\left.p<.001 ; \eta^{2}=.002\right]$.

CONCLUSIONS: The results clearly indicate the need to connect multiple sectors that affect the lifestyle of the general population. Possible solution is an interdisciplinary approach to the evaluation of the fundamental environmental factors influencing the level of PA (walkability; SES; participation in organized and voluntary PA; neighborhood safety; type of transportation; size of the community).
\end{abstract}

Keywords: Questionnaire, built environment, walkability, size of the residence, lifestyle.

\section{INTRODUCTION}

Correlates and determinants of daily physical activity (PA) become an important research and policy issue in recent decades abroad. Issues related to energy and intensity (Ainsworth et al., 2000; Ainsworth \& Tudor-Locke, 2005), international comparative studies (Bauman et al., 2009), in psychological theories

\footnotetext{
* Address for correspondence: Josef Mitáš, Institute of Active Lifestyle, Faculty of Physical Culture, Palacký University, tř. Míru 115, 77111 Olomouc, Czech Republic. E-mail: josef.mitas@upol.cz
}

(Sallis \& Owen, 2002) or in translation research into policy (Smith \& Bird, 2004; USDHHS, 2000) are very often discussed. In the Czech Republic is apparent similar trend in research of intensity and structure of PA (Frömel et al., 2006; Frömel, Mitáš, \& Kerr, 2009), of socio-economic impact (Mitáš, Frömel, et al., 2007; Pelclová et al., 2008) or psychosocial correlates of PA (Sigmund et al., 2008). The issues of unhealthy lifestyles in developed countries are solved through strategic documents (Commission of the European Communities, 2007a, 2007b; USDHHS, 2000, 2008).

Topics related to external influences on lifestyle and PA, such as the effect of the physical and built 
environment, are frequently discussed in relation to body weight (Adams et al., 2011), to community design (Frank \& Engelke, 2001), to participation and promotion of PA (Humpel, Owen, \& Leslie, 2002; Sallis, Bauman, \& Pratt, 1998), active transportation (Sallis, Frank, Saelens, \& Kraft, 2004) or adherence to PA in varying environments (Sallis, King, Sirard, \& Albright, 2007). These associations should lead to solve architectural projects from the perspective of both urban design and PA (Frank, Schmid, Sallis, Chapman, \& Saelens, 2005; Frumkin, 2002; Rodriguez, Khattak, \& Evenson, 2006).

The global "epidemic" of obesity and unhealthy lifestyles is apparent in economically developed countries. Developing countries (especially from the former "Communist bloc"), quickly take over unhealthy habits and copy the negative trends known from developed countries (Frömel, Mitáš, \& Kerr, 2009). These newly "democratized" countries did not grow in a process of changing lifestyle, which was carried out in developed countries in the second half of the $20^{\text {th }}$ century. Socioeconomic status, which is associated with a healthier way of life of adults (Giles-Corti \& Donovan, 2002), and adolescents (Maher \& Olds, 2011; Tremblay \& Willms, 2003) differs in the Czech Republic and other post-communist countries (Frömel, Mitáš, \& Kerr, 2009). The standard of living of the population is below the European Union average and lifestyle and health topics correspond to this development. Busy work and personal life on one hand, the convenience and availability of consumerism on the other hand, lead to an increase in obesity rates and to a decrease in health status and physical activity in the general population (Mitáš et al., 2007). Neighborhood environments in the evaluation of physical activity of the population seems to be one of the important aspects in prevention of unhealthy lifestyle and physical inactivity (Brownson, Hoehner, Day, Forsyth, \& Sallis, 2009; Frank, Engelke, \& Schmid, 2003; Sallis \& Kerr, 2006). Based on the knowledge from developed countries we were interested whether similar associations between perceived neighborhood walkability and PA in different size of location can be found in post-communist countries like Czech Republic in national sample of adults.

\section{AIM}

The main objective of this study was to analyze the relationship between the structure of physical activity and perceived neighborhood walkability of the adult population of the Czech Republic. Further aims were to find out gender differences in structure of PA and the role of the size of location in the level of PA in Czech adults.

\section{METHODS}

Nationwide data collection of adults PA was done in regions in the Czech Republic between the years 2005-2009 using the International Physical Activity Questionnaire (IPAQ - long version) and Neighborhood Environment Walkability Scale - Abbreviated (ANEWS) questionnaires. The research sample was randomly selected from the addresses database available at the Ministry of Interior of the Czech Republic. Distributors implemented the research at the randomly selected addresses within the regions as instructed. The research was carried out among respondents aged 15-69 years (IPAQ and pedometer monitoring) and 20-65 years (ANEWS questionnaire and monitoring of PA using accelerometers). A total of 8,708 inhabitants of the Czech Republic (3,868 males a 4,840 females) aged $40.84 \pm 9.09$ participated in the research study. The data obtained from the questionnaires were processed and entered into the database. Walkability was determined as a measure of how friendly an area (built environment) is for residents to perform daily activities around the neighborhood within walking distance. According to the criteria, areas with lower or higher walkability have been selected, which is also associated with the PA level. Random sample was specified by gender and ratio between males and females within the regions of the Czech Republic (Czech Statistical Office, 2009). Males $(N=3,868)$ were aged $40.79 \pm 9.62$ (height $180.31 \pm 6.84 \mathrm{~cm}$; weight $84.58 \pm 12.01 \mathrm{~kg}$; BMI $\left.26.03 \pm 3.55 \mathrm{~kg} / \mathrm{m}^{2}\right)$; females $(N=4,840)$ were aged $40.87 \pm 8.65$ (height $167.03 \pm 6.08 \mathrm{~cm}$; weight $65.88 \pm 10.50 \mathrm{~kg} ; \quad$ BMI $\left.23.62 \pm 3.64 \mathrm{~kg} / \mathrm{m}^{2}\right)$. The Prague region was excluded from the analyses due to a non-representative sample $(n=452)$. Meeting the PA guidelines accounts for meeting the general PA recommendations of vigorous and moderate intensity PA including walking recognized by global institutions (World Health Organization). For the Czech population the advanced recommendation criteria were used, as inhabitants of the Czech Republic compared to other countries showed higher amount of realized PA. The data were statistically analyzed using Statistica 9 software and SPSS 18. Basic descriptive statistics, KruskalWallis ANOVA test (StatSoft CR, 2008; SPSS CR, 2008) and "effect size" $\eta^{2}$ (Morse, 1999) were used to characterize associations. Cohen coefficient "effect size" $d$ (Cortina \& Nouri, 2000) was used to assess the internal group variability. The level of statistical significance was set by $p \leq .001$.

\section{RESULT AND DISCUSSION}

This paper presents methods used within the international research on physical activity and neighborhood environment. Regional specificities and different 
lifestyle, based on local conditions, indicate regional differences within the Czech population in the implementation of PA in relation to the neighborhood environment. The results show that the level of total PA among Czechs is high which denotes the population as highly active (more than half of the adult population).

It is apparent that neighborhood walkability plays an important role in participation in leisure time PA nearby the place of the residence (De Bourdeaudhuij, Sallis, \& Saelens, 2003; Van Dyck, Deforche, Cardon, \& De Bourdeaudhuij, 2009). Perceived neighborhood walkability derived from questionnaires was verified in previous international studies (Humpel, Marshall, Leslie, Bauman, \& Owen, 2004; Humpel, Owen, \& Leslie, 2002; Saelens \& Handy, 2008) saying that there is a high correlation between higher walkability and higher level of moderate to vigorous PA of respondents living in these areas. This indicates that it is possible to get a relevant finding from subjective assessment of neighborhood environments associated to the structure of PA of respondents living in specific areas. Analysis of the structure of PA intensity (vigorous, moderate and walking) documents whether the neighborhood walkability affects PA of Czech adults (Figure 1). We have found a significant difference in total level of PA between males and females. However the level of weekly PA is not significantly affected by the neighborhood walkability in both males and females $[\mathrm{H}(3,8708)$ $\left.=19.60 ; p \leq .001 ; \eta^{2}=.002\right]$. We can argue that differences in the walkability of the environment do not significantly influence PA in men, although slightly more active are those living in low walkable areas. Women indicated higher total weekly PA if they lived in a high walkable neighborhood, but the difference was not significant as well. High level of total walking also predicts that the neighborhood setting is walking friendly in both low and high walkable areas. This suggests that neighborhood environment across the Czech Republic still remains pedestrian friendly and should be thus maintained and further developed. Small differences in total PA in both males and females (less than 40 MET-min./week) indicate that the level of walkability does not influence the total PA of Czech adults.

The results of the IPAQ questionnaire (Figure 2) show that males realize significantly more PA than females $(p \leq .001 ; d=0.124)$. This difference is caused by a higher amount of vigorous PA in males ( $p \leq .001 ; d=0.414)$. On the other hand, females realize more moderate PA $(p=.273 ; d=0.012)$ and walking $(p \leq .001 ; d=0.093)$ than males. The difference in walking was $200 \mathrm{MET}$-min./week, which confirms that females realize more regular routes for shopping or services by walking. The main difference between males and females represents the difference in vigorous PA, which is characterized by heavy load, harder breathing and shorter duration, corresponding to the structure of the activities realized by males and females. Males more often realize soccer, swimming, cycling, tennis and team sports (more often vigorous PA), females realize mostly swimming, cycling, aerobics and walking (more often moderate PA).

Physical activity of the Czech adult population is significantly influenced by the size of the location where respondents live. Results of the study confirm proposed statement in previous studies (Frömel et al., 2004; Frömel, Mitáš, \& Kerr, 2009; Mitáš \& Frömel, 2011) that PA in residents of smaller communities is higher than those living in big cities.

Analysis of the structure of PA in males (Figure 3) indicates a significant difference in vigorous $\mathrm{PA}[\mathrm{H}(3$, $\left.3678)=17.60 ; p \leq .001 ; \eta^{2}=.03\right]$. Highest significance was found between residents of a large city and a village $(p \leq .001 ; d=0.209)$. Highest significant difference in moderate PA of males $[\mathrm{H}(3,3678)=174.53$; $\left.p \leq .001 ; \eta^{2}=.05\right]$ was found between residents of a large city and a village $(p \leq .001 ; d=0.666)$; between residents of a medium-sized town and a village $(p \leq .001 ; d=0.461)$; and between residents of a small

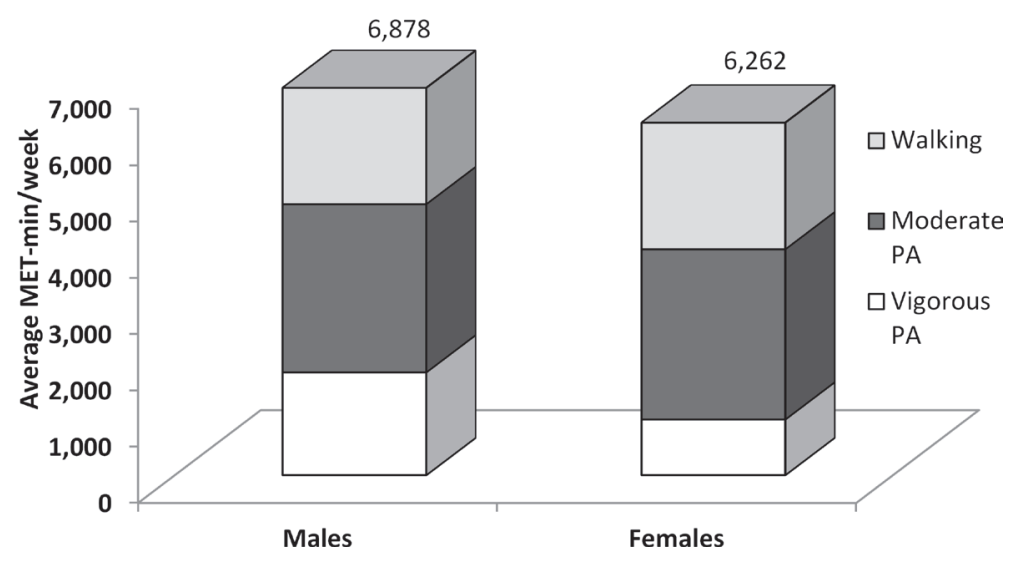

Figure 1. The structure of weekly physical activity of males $(N=3,868)$ and females $(N=4,840)$ based on the level of walkability 


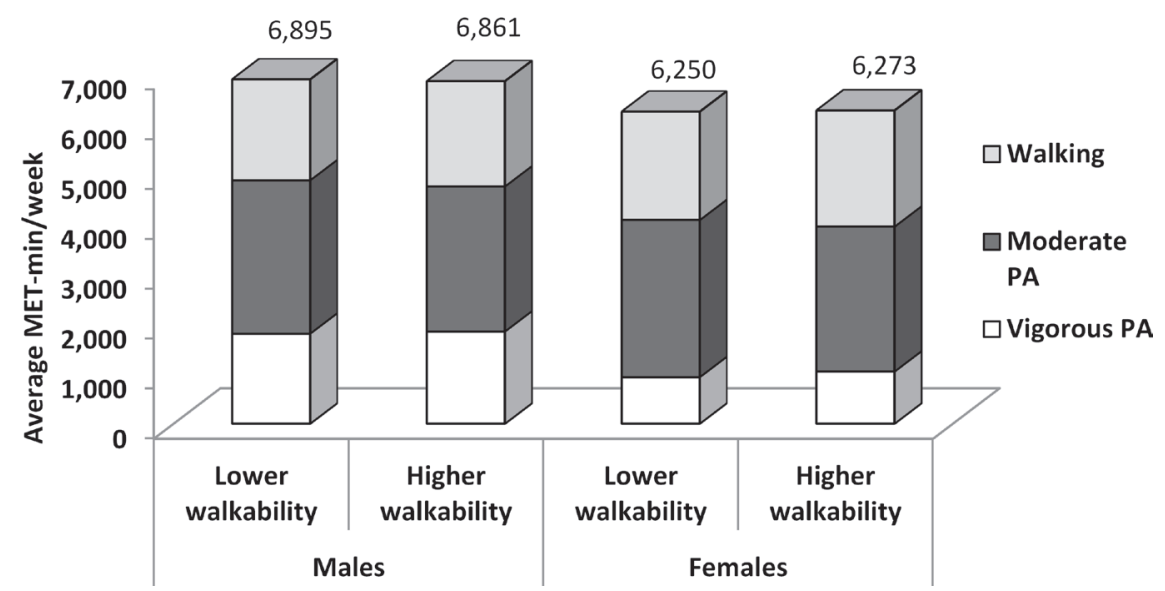

Figure 2. The structure of weekly physical activity of Czech males $(N=3,868)$ and females $(N=4,840)$

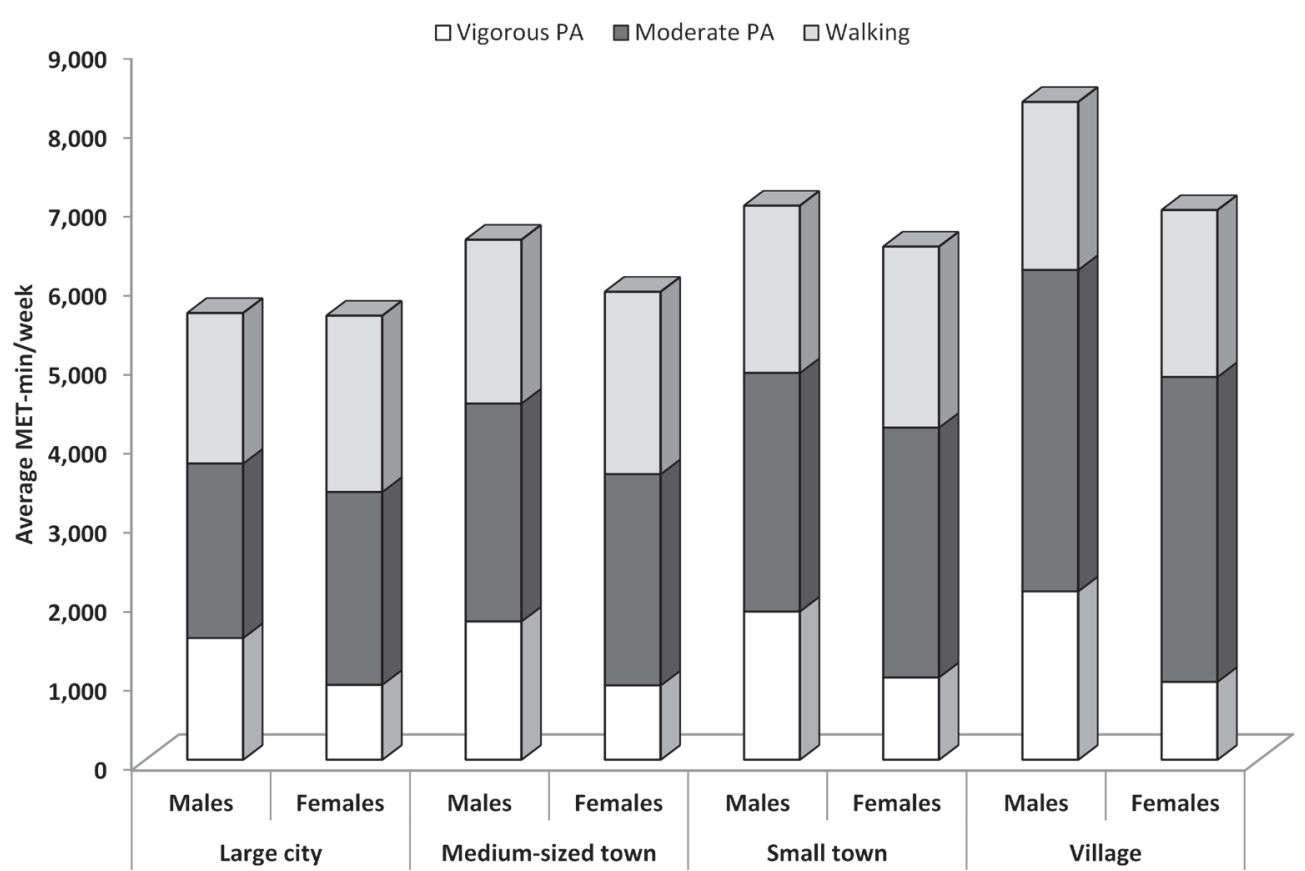

Figure 3. The structure of weekly physical activity of males $(N=3,868)$ and females $(N=4,840)$ based on the size of the residence. Note. Large city = place with more than 100,000 residents, medium-sized town $=$ place with 30,000 to 100,000 residents, small town $=$ place with 1,000-29,999 residents, village $=$ place with less than 1,000 residents.

town and a village $(p \leq .001 ; d=0.351)$. No significant difference in walking in various size of the residence in males was found. The total PA is significantly higher in residents of villages compared to males living in larger areas (large city, medium-sized and small town) $\left[\mathrm{H}(3,3678)=102.23 ; p \leq .001 ; \eta^{2}=.03\right]$.

We found no significant difference in vigorous PA and in walking in various size of the residence in females (Figure 3). The highest significant difference in moderate PA of females $[\mathrm{H}(3,4578)=135.56 ; p \leq .001$; $\eta^{2}=.03$ ] was found between residents of a large city and a village $(p \leq .001 ; d=0.482)$; between resi- dents of a medium-sized town and a village ( $p \leq .001$; $d=0.416$ ); between residents of a small town and a village ( $p \leq .001 ; d=0.197$ ); and between residents of a medium-sized town and a small town $(p \leq .001$; $d=0.202$ ). The total PA is higher in residents of villages compared to females living in lager localities (cities and towns) $\left[\mathrm{H}(3,4578)=38.44 ; p \leq .001 ; \eta^{2}=.008\right]$.

Residents of smaller communities (up to 1,000 and up to 30,000 inhabitants) reported significantly higher level of PA than those living in large cities (over 30,000 and over 100,000 inhabitants) $[H(7,8256)=162.68$; $\left.p \leq .001 ; \eta^{2}=.02\right]$. This trend is apparent in both males 
and females and we can set this state as a specificity of the Czech adult population as stated previously (Frömel, Mitáš, \& Kerr, 2009). Studies from other countries, however, still tend to suggest greater walking and PA in more compact urban environments, where access to PA facilities may be greater, distances may be shorter and sidewalks are often present to facilitate walking for transportation (Ham, Macera, \& Lindley, 2005; Reis et al., 2004; Schwanen \& Mokhtarian, 2005). Only limited national studies indicated similar results like this Czech study, used town size and compared towns with greater than 100,000 residents and those with fewer than 1,000 (Badland \& Schofield, 2006; Bertrais et al., 2004). The association with activity might be explained by occupational activities or higher incidence of agricultural work or manual labor in rural environments. In addition, activity may be higher in smaller towns due to safer neighborhoods and access to forest trails in comparison to larger cities where walking distances may be longer according to the size of the city. Shorter distances in smaller communities motivate people to walk or bike to destinations (shops, services, facilities). Larger cities are characterized by better infrastructures, thus longer distances and subjectively perceived safety indicate increased use of public transport or personal cars for transportation (Frömel et al., 2004).

Czech society is still relatively marginally differentiated in terms of PA realization and is characterized as highly active (Frömel, Mitáš, \& Kerr, 2009). So we differ with the results of international studies in developed countries that argue that residents of PA friendly neighborhood environments initiate higher level of total PA compared to the inhabitants of areas with lower walkability (De Bourdeaudhuij, Sallis, \& Saelens, 2003; Frumkin, 2002; Humpel, Marshall, Leslie, Bauman, \& Owen, 2004; Humpel, Owen, \& Leslie, 2002; Saelens \& Handy, 2008). There exist evidence (ČLS, 2006; Láchová \& Daňková, 2010) in increasing overweight and obesity rates among residents of the Czech Republic, as well for residents of developed countries, which are related to the non-communicable diseases linked to unhealthy lifestyles. Neighborhood environment motivating people to be physically active within their community may help in programs aimed at healthy living communities and healthier residents of these areas.

General health recommendations for PA are met by the total of $64.1 \%$ of females and $59.9 \%$ of males in the Czech population (results not presented). This means that they simultaneously meet at least one or more of the advanced criteria of recommended amount of realized PA (at least 60 minutes in 5 or more days of vigorous or moderate PA or walking per week). However, about $40 \%$ of the population of the Czech Republic does not meet even basic health recommendations for
PA. Within the population with $50 \%$ of overweight and obese people this is one of the key points that need to be addressed while changing the health indicators based on knowledge of the economic costs of less active population.

\section{Strengths \& limitations of study}

This study benefits from a large sample size in a unique population, with multiple social and environmental measures related to physical activity and walking. The study did not include objective measures of physical activity and did not analyze the distinction between walking for different purposes, such as leisure and transportation.

\section{CONCLUSIONS}

The paper presents an approach which can be applied in research of neighborhood environment and PA in the Czech adult population. The results clearly indicate the need to connect multiple sectors that affect population lifestyle. Physical activity of the population in all regions of the Czech Republic is balanced. People living in low walkable areas are not less active than those living in high walkable locations and this confirms the low variability in neghborhood environment in the Czech Republic. Females are less active than males but this is basically because of their level of vigorous PA. Residents of smaller communities reported the highest level of total weekly PA which is a different conclusion compared to other country studies.

The interest in research of factors linking neighborhood environment and socio-demographic factors aiming at behavioral changes has been growing. Topics focused on leisure and environment become part of the study programs or subjects. It is desirable to include these topics into independent disciplines into a field with key determinants of research. The interrelation of biomedical, epidemiological and natural scientific fields in order to change lifestyle habits and personal health within the population has gained its validity and its research base is growing. Behavioral changes with regard to PA in different neighborhood environments appear to be a viable interdisciplinary filed.

\section{ACKNOWLEDGMENTS}

The study has been supported by the research grant from the Ministry of Education, Youth and Sports of the Czech Republic (No. MSMT 6198959221) "Physical Activity and Inactivity of the Inhabitants of the Czech Republic in the Context of Behavioral Changes" and by the internal grant UP FTK_2012:013 "Neighborhood Environments and Physical Activity of the Population of Selected Czech Cities". 


\section{REFERENCES}

Adams, M. A., Sallis, J. F., Kerr, J., Conway, T. L., Saelens, B. E., Frank, L. D., ... Cain, K. L. (2011). Neighborhood environment profiles related to physical activity and weight status: A latent profile analysis. Preventive Medicine, 52(5), 326-331.

Ainsworth, B. E., Haskell, W. L., Whitt, M. C., Irwin, M. L., Swartz, A. M., Strath, S. J., ... Leon, A. S. (2000). Compendium of physical activities: An update of activity codes and MET intensities. Medicine and Science in Sports and Exercise, 32(Suppl. 9), 498-516.

Ainsworth, B. E., \& Tudor-Locke, C. (2005). Health and physical activity research as presented in RQES. Research Quarterly for Exercise and Sport, 76(Suppl. 2), 40-52.

Badland, H., \& Schofield, G. (2006). Understanding the relationship between town size and physical activity levels: A population study. Health \& Place, 12(4), 538-546.

Bauman, A., Bull, F., Chey, T., Craig, C. L., Ainsworth, B. A., Sallis, J. F., Bowles, H. R., Hagströmer, M., Sjöström, M., Pratt, M., \& The IPS Group (2006). The international prevalence study on physical activity: Results from 20 countries. International Journal of Behavioral Nutrition and Physical Activity, 6, 21. doi:10.1186/1479-5868-6-21.

Bertrais, S., Preziosi, P., Mennen, L., Galan, P., Hercberg, C., \& Oppert, J. M. (2004). Sociodemographic and geographic correlates of meeting current recommendations for physical activity in middle-aged French adults: The supplémentation en vitamines et minéraux antioxydants (SUVIMAX) study. American Journal of Public Health, 94(9), 1560-1566.

Brownson, R. C., Hoehner, C. M., Day, K., Forsyth, A., \& Sallis, J. F. (2009). Measuring the built environment for physical activity: State of the science. American Journal of Preventive Medicine, 36(Suppl. 4), 99-123.

Commission of the European Communities. (2007a). White paper - Strategy on nutrition, overweight and obesity-related health issues. Brussel: Commission of the European Communities.

Commission of the European Communities. (2007b). White paper on sport. Brussel: Commission of the European Communities.

Cortina, J. M., \& Nouri, H. (2000). Effect size for ANO$V A$ designs. Thousand Oaks, CA: Sage publications.

Czech Medical Association (ČLS). (2006). Životní styl a obezita - longitudinální epidemiologická studie prevalence obezity v $\breve{C} R$ [Lifestyle and obesity - longitudinal epidemiology study of obesity prevalence in CR]. Praha: STEM/MARK.

Czech Statistical Office. (2009). Statistical yearbook of the Czech Republic 2009. Praha: Scientia.
De Bourdeaudhuij, I., Sallis, J. F., \& Saelens, B. E. (2003). Environmental correlates of physical activity in a sample of Belgian adults. American Journal of Health Promotion, 18(1), 83-92.

Frank, L. D., \& Engelke, P. (2001). The built environment and human activity patterns: Exploring the impacts of urban form on public health. Journal of Planning Literature, 16(2), 202-218.

Frank, L. D., Engelke, P., \& Schmid, T. L. (2003). Health and community design: The impact of the built environment on physical activity. Washington, DC: Island Press.

Frank, L. D., Schmid, T. L., Sallis, J. F., Chapman, J., \& Saelens, B. E. (2005). Linking objectively measured physical activity with objectively measured urban form: Findings from SMARTRAQ. American Journal of Preventive Medicine, 28(Suppl. 2), 117-125.

Frömel, K., Sigmund, E., Sigmundová, D., Formánková, S., Mitáš, J., Neuls, F., ... Horák, S. (2004). Physical activity of men and women 18 to 55 years old in Czech Republic. In F. Vaverka (Ed.), Movement and Health (pp. 169-173). Olomouc: Univerzita Palackého.

Frömel, K., Bauman, A., Bláha, L., Feltlová, D., Fojtík, I., Hájek, J., ... Šebrle, Z. (2006). Intenzita a objem pohybové aktivity 15-69leté populace České republiky [Intensity and volume of physical activity in Czech population aged 15-69]. Česká kinantropologie, 10(1), 13-27.

Frömel, K., Mitáš, J., \& Kerr, J. (2009). The associations between active lifestyle, the size of a community and SES of the adult population in the Czech Republic. Health \& Place, 15(2), 447-454.

Frumkin, H. (2002). Urban sprawl and public health. Public Health Reports, 117(3), 201-217.

Giles-Corti, B., \& Donovan, R. J. (2002). Socioeconomic status differences in recreational physical activity levels and real and perceived access to a supportive physical environment. Preventive Medicine, 35(6), 601-611.

Ham, S. A., Macera, C. A., \& Lindley, C. (2005). Trends in walking for transportation in the United States, 1995 and 2001. Preventing Chronic Disease, 2(4), 14.

Humpel, N., Marshall, A. L., Leslie, E., Bauman, A., \& Owen, N. (2004). Changes in neighborhood walking are related to changes in perceptions of environmental attributes. Annals of Behavioral Medicine, 27(1), 60-67.

Humpel, N., Owen, N., \& Leslie, E. (2002). Environmental factors associated with adults' participation in physical activity. American Journal of Preventive Medicine, 22(3), 188-199.

Láchová, J., \& Daňková, Š. (2010). Evropské výběrové šetření o zdravotním stavu v ČR - EHIS CR: In- 
dex tělesné hmotnosti, fyzická aktivita, spotřeba ovoce a zeleniny [European selected research on health status in Czech Republic - EHIS CR: Body Mass Index, physical activity, fruit and vegetable consumption]. Aktuální informace Ústavu zdravotnických informací a statistiky České republiky, 70, 1-11. Retrieved from http://www.uzis.cz/system/ files/70_10.pdf

Maher, C. A., \& Olds, T. S. (2011). Minutes, MET minutes, and METs: Unpacking socio-economic gradients in physical activity in adolescents. Journal of Epidemiology and Community Health, 65(2), 160-165.

Mitáš, J., \& Frömel, K. (2011). Pohybová aktivita dospělé populace české republiky: Přehled základních ukazatelů za období 2005-2009 [Physical activity of adult population in the Czech Republic: Overview of basic indicators for the period 20052009]. Tělesná kultura, 34(1), 9-21.

Mitáš, J., Frömel, K., Bláha, L., Nykodým, J., Suchomel, A., Šebrle, Z., ... Fojtík, I. (2007). Vliv faktorů socioekonomického statutu na životní styl obyvatel České republiky [Influence of socioeconomical status on the lifestyle of the Czech Republic population]. Tělesná kultura, 30(1), 66-83.

Morse, D. T. (1999). MINSIZE2: A computer program for determining effect size and minimum sample size for statistical significance for univariate, multivariate, and nonparametric tests. Educational and Psychological Measurement, 59(3), 518-531.

Pelclová, J., Vašičková, J., Frömel, K., Bláha, L., Feltlová, D., Fojtík, I., ... Šebrle, Z. (2008). Vliv vybraných faktorů na pohybovou aktivitu a sezení u zaměstnaných a osob v důchodu ve věku 55-69 let [Influence of selected factors on physical activity and sedentary behavior in employed and retired inhabitants of the Czech Republic aged 55-69]. Čská kinantropologie, 12(4), 49-59.

Reis, J. P., Bowles, H. R., Ainsworth, B. E., Dubose, K. D., Smith, S., \& Laditka, J. N. (2004). Nonoccupational physical activity by degree of urbanization and US geographic region. Medicine and Science in Sports and Exercise, 36(12), 2093-2098.

Rodríguez, D. A., Khattak, A. J., \& Evenson, K. R. (2006). Can new urbanism encourage physical activity? Journal of the American Planning Association, 72(1), 43-54.

Saelens, B. E., \& Handy, S. L. (2008). Built environment correlates of walking: A review. Medicine and Science in Sports and Exercise, 40(Suppl. 7), 550566.

Sallis, J. F., Bauman, A., \& Pratt, M. (1998). Environmental and policy interventions to promote physical activity. American Journal of Preventive Medicine, 15(4), 379-397.
Sallis, J. F., Frank, L. D., Saelens, B. E., \& Kraft, K. (2004). Active transportation and physical activity: Opportunities for collaboration on transportation and public health research. Transportation Research Part A: Policy and Practice, 38(4), 249-268.

Sallis, J. F., King, A. C., Sirard, J. R., \& Albright, C. L. (2007). Perceived environmental predictors of physical activity over 6 months in adults: Activity counseling trial. Health Psychology, 26(6), 701-709.

Sallis, J. F., \& Kerr, J. (2006). Physical activity and the built environment. President's Council on Physical Fitness and Sports Research Digest, 7(4), 1-8.

Sallis, J. F., \& Owen, N. (2002). Ecological model of health behavior. In K. Glanz, B. K. Rimer, \& F. M. Lewis (Eds.), Health behavior and health education: Theory, research, and practice (pp. 462-484). San Francisco, CA: Jossey-Bass.

Schwanen, T., \& Mokhtarian, P. L. (2005). What if you live in the wrong neighborhood? The impact of residential neighborhood type dissonance on distance traveled. Transportation Research Part D: Transport and Environment, 10(2), 127-151.

Sigmund, E., Mitáš, J., Vašíčková, J., Sigmundová, D, Chmelík, F., Frömel, K., ... Bláha, L. (2008). Biosociální proměnné pohybové aktivity dospělých obyvatel vybraných metropolí České republiky [Bio-social variables of PA in adults in selected cities in the Czech Republic]. Ceská kinantropologie, 12(4), 9-20.

Smith, A., \& Bird, S. (2004). From evidence to policy: Reflections on emerging themes in health-enhancing physical activity. Journal of Sports Science, 22(8), 791-799.

SPSS CR spol. s r. o. (2009). IBM SPSS Statistics 18.0. [Computer software]. Praha: SPSS CR spol. s r. o.

StatSoft CR s r. o. (2009). Statistica 9.0. [Computer software]. Praha: StatSoft CR s r. o.

Tremblay, M. S., \& Willms, J. D. (2003). Is the Canadian childhood obesity epidemic related to physical inactivity? International Journal of Obesity, 27(9), 1100-1105.

U. S. Department of Health and Human Services (USDHHS). (2000). Healthy people 2010: Understanding and improving health. Washington, DC: U. S. Department of Health and Human Services.

U. S. Department of Health and Human Services (USDHHS). (2008). 2008 Physical activity guidelines for Americans. Washington, DC: U. S. Department of Health and Human Services

Van Dyck, D., Deforche, B., Cardon, G., \& De Bourdeaudhuij, I. (2009). Neighborhood walkability and its particular importance for adults with a preference for passive transport. Health \& Place, 15(2), 496-504. 


\section{POHYBOVÁ AKTIVITA DOSPĚLÝCH OBYVATEL ČESKÉ REPUBLIKY V OKOLÍ MÍSTA BYDLIŠTĚ - NÁRODNÍ ŠETŘENÍ}

(Souhrn anglického textu)

VÝCHODISKA: Mezinárodní výzkumy vztahují pohybovou aktivitu (PA) k dalším faktorům jako jsou podmínky prostředí, kultura, a politika místních podmínek. Velmi často jsou zmiňovány vnější vlivy na životní styl a PA, jako je vliv fyzického a zastavěného prostředí. Ukazuje se, že podmínky prostředí okolí místa bydliště jsou jedním z důležitých aspektů při prevenci nezdravého způsobu života a pohybové inaktivity.

CÍLE: Hlavním cílem práce je analýza vztahů mezi pohybovou aktivitou (PA) a prostředím místa bydliště dospělé populace České republiky. Práce se snaží definovat základní koreláty PA v závislosti na podmínkách prostředí a dalších socio-demografických aspektech.

METODIKA: Celorepublikový sběr dat o PA dospělé populace probíhal v rámci regionů České republiky 2005-2009 pomocí dotazníků IPAQ (long) a ANEWS.
VÝSLEDKY: Výsledky ukazují, že muži realizují signifikantně více intenzivní PA než ženy, zatímco ženy realizují více středně zatěžující PA a chůze než muži. PA obyvatel menších sídel je vyšší než u obyvatel velkých měst. Na velikost týdenní PA české populace nemá signifikantní vliv míra chodeckosti $[\mathrm{H}(3,8708)=19.60$; $\left.p<.001 ; \eta^{2}=.002\right]$.

ZÁVĚRY: $Z$ výsledků práce jasně vyplývá, že je třeba propojení více oborů ovlivňujících životní styl běžné populace. Jednou $\mathrm{z}$ cest je interdisciplinární prístup při hodnocení zásadních faktorů podmínek prostředí ovlivňujících PA (chodeckost; SES; účast v organizovaných a neorganizovaných volnočasových PA; bezpečnost $\mathrm{v}$ okolí bydliště; způsob transportu; velikost místa bydliště).

Kličová slova: dotazník, zastavěné prostréedí, chodeckost, velikost sídla, životní styl. 